JURNAL CAKRAWARTI, VOL. 04 NO. 01 FEB-JUL 2021

\title{
DAMPAK DARI PANDEMI COVID-19 MELAKUKAN STUDY WORK FROM HOME
}

\author{
Ni Wayan Sutiani \\ Fakultas Ilmu Sosial dan Ilmu Politik Universitas Mahendrdatta \\ Email : sutianiwayan42@gmail.com
}

\begin{abstract}
Abstrak - Berdasarkan laporan ABC News 7 Maret 2020, penutupan sekolah terjadi di lebih dari puluhan negara karena wabah COVID-19. Menurut data Organisasi Pendidikan, Keilmuan, dan Kebudayaan PBB (UNESCO), setidaknya ada 290,5 juta siswa di seluruh dunia yang aktivitas belajarnya menjadi terganggu akibat sekolah yang ditutup. Di tingkat perguruan tinggi Amerika serikat, wabah virus corona juga menunjukkan intervensinya. Gara-gara COVID-19, program pertukaran mahasiswa antar negara harus distop. Ini banyak dilakukan oleh universitas di AS. Tujuan dari penelitian ini adalah untuk mengidentifikasi mendapatkan informasi kendala proses belajar mengajar secara online di rumah akibat dari adanya pandemic COVID-19. Penelitian menggunakan metode studi kasus eksplorasi dan pendekatan penelitiannya menggunakan metode studi kasus kualitatif yang digunakan untuk mendapatkan informasi kendala dan akibat dari pandemic COVID-19 terhadap kegiatan proses belajar mengajar di Universitas Mahendradatta. Dalam penelitian ini, responden sebanyak 6 (enam) orang diantaranya adamahasiswa, orang tua dan dosen. Untuk tujuan kerahasiaan, responden diberi inisial R1, R2, R3, R4, R5 dan R6. Hasil dari penelitian ini yaitu terdapat beberapa kendala yang dialami oleh mahasiswa dalam kegiatan belajar mengajar online yaitu penambahan biaya kuota internet yang meningkat hingga 3 kali lipat dari biasanya, kemudian kendala pada sinyal internet sehingga mengakibatkan kegiatan belajar mengajar menjadi kurang efektif
\end{abstract}

Kata kunci: pandemi covid-19, belajar mengajar, online, bekerja dari rumah

Abstract - The purpose of this study was to identify obtaining information on the constraints of the teaching and learning process online at home as a result of the presence of a COVID19 pandemic. The study uses an exploratory case study method and its research approach uses a qualitative case study method that is used to obtain information on the constraints and consequences of the COVID-19 pandemic on teaching and learning activities at Mahendradatta University. In this study, there were 6 (six) respondents including students, parents and lecturers. For confidentiality purposes, respondents are given the initials R1, $R 2, R 3, R 4, R 5$ and R6. Semi-structured interviews were conducted and a list of questions compiled for interviews was developed based on the related literature. Respondents for this study were students at various state / private universities in Bali. The results of this study are that there are some obstacles experienced by students in online teaching and learning 
activities, namely the addition of internet quota costs that increase up to three times the usual rate, then constraints on internet signals resulting in teaching and learning activities become less effective because of faltering signals that can sometimes cut off the conversation just like that, or the conversation became less clear which resulted in mis communication. There are also those who do not understand how to use the application, then the sophistication or type of each different cellphone or laptop, which causes the electronic device to feel heavier on the memory or ram, then when the teaching and learning process is taking place the battery is drained faster, jammed and hot. Then the most dangerous is the eye health that lasts a long time in front of your cellphone or computer or laptop, due to high radiation exposure from the screen or LCD. Parents also complained that with a study from home, expenses were increasing, and UKT costs had to be paid.

Keywords: pandemy covid-19, teaching and learning, work from home

\section{PENDAHULUAN}

Pandemi COVID-19 adalah krisis kesehatan yang pertama dan terutama didunia. Banyak negara memutuskan untuk menutup sekolah, perguruan tinggi dan universitas. Perserikatan Bangsa-Bangsa (PBB) menjadi gusar dengan adanya fakta tersebut. Organisasi Internasional yang bermarkas di New York, AS, itu menangkap bahwa pendidikan menjadi salah satu sektor yang begitu terdampak oleh virus corona. Parahnya lagi, hal itu terjadi dala tempo yang cepat dan skala yang luas. Berdasarkan laporan ABC News 7 Maret 2020, penutupan sekolah terjadi di lebih dari puluhan negara karena wabah COVID-19. Menurut data Organisasi Pendidikan, Keilmuan, dan Kebudayaan PBB (UNESCO), setidaknya ada 290,5 juta siswa di seluruh dunia yang aktivitas belajarnya menjadi terganggu akibat sekolah yang ditutup. Di tingkat perguruan tinggi Amerika serikat, wabah virus corona juga menunjukkan intervensinya. Garagara COVID-19, program pertukaran mahasiswa antarnegara harus distop. Ini banyak dilakukan oleh universitas di AS.

Melihat kondisi Italia yang merana karena corona, beberapa universitas meminta seluruh mahasiswanya kembali dari program study exchange di Italia. Kebijakan ini menyusul keputusan Pusat Pencegahan dan Pengendalian Penyakit (CDC) yang menempatkan Italia dari status darurat Level 2 ke Level 3 pada 26 Februari lalu. Universitas Elon, Universitas Fairfield, Universitas Internasional Florida, Universitas Tampa, Universitas Gonzaga, Universitas Loyola Chicago, Universitas Miami-Ohio, Universitas Negeri Penn, Universitas Stanford, Universitas Syracuse, Universitas Taman Maryland-College, Universitas Miami dan Universitas Villanova telah meminta mahasiswa mereka untuk segera meninggalkan Italia dan kembali ke AS. Virus coronalockdown di New York Amerika Serikat Beberapa mahasiswa, seperti yang ada di Universitas Villanova, juga diminta untuk memenuhi masa karantina selama 14 hari sebelum kembali ke kampus. Di Washington, di mana banyak kasus virus corona telah dilaporkan, pejabat kesehatan mengatakan tidak ada protokol yang ditetapkan untuk penutupan sekolah. Sebanyak 13 negara termasuk Cina, Italia dan Jepang telah menutup sekolah-sekolah di seluruh negeri dalam upaya untuk menghentikan penyebaran virus mirip flu tersebut. Itu mempengaruhi hampir 290 juta siswa, kata UNESCO. Sebagian besar siswa 
berasal dari China, tempat wabah itu berasal. Di seluruh negeri, termasuk wilayah administrasi khusus Hong Kong dan Makau, lebih dari 233 juta siswa tidak sekolah karena virus. Itu diikuti oleh Jepang, yang memiliki hampir 16,5 juta siswa yang dipindahkan, menurut data UNESCOInstitute of Statistics.

Sejumlah sekolah di Amerika Serikat telah membatalkan kelas akibat virus corona. Antaranya adalah Mariner High School dan Discovery Elementary School, yang terletak di negara bagian Washington, yang telah melihat peningkatan tajam dalam kasus yang dikonfirmasi. Negara bagian New York dan Kota New York juga telah menutup beberapa sekolah setelah pejabat kesehatan mengkonfirmasi setidaknya 22 kasus di seluruh negara bagian. Pejabat Los Angeles, ketika menyatakan keadaan darurat pada hari Rabu, mengatakan kepada orang tua bahwa penutupan sekolah adalah suatu kemungkinan dan harus disiapkan. Pejabat kesehatan saat ini tidak merekomendasikan penutupan sekolah jika tidak ada kasus coronavirus lokal. Sebaliknya, mereka menekankan perilaku sehat seperti mencuci tangan dengan air sabun panas, tinggal di rumah saat sakit dan menutupi batuk. UNESCO akan mengadakan pertemuan darurat pada 10 Maret tentang penutupan sekolah terkait coronavirus. Badan tersebut mengatakan mendukung implementasi program dan platform pembelajaran jarak jauh skala besar untuk menjangkau siswa dari jarak jauh. Dampak pandemi corona kini mulai merambah dunia pendidikan, pemerintah pusat hingga daerah memberikan kebijakan untuk meliburkan seluruh lembaga pendidikan.

Hal ini dilakukan sebagai upaya mencegah meluasnya penularan virus corona. Diharapakan dengan seluruh lembaga pendidikan tidak melaksanakan aktivitas seperti biasanya, hal ini dapat meminimalisir menyebarnya penyakit covid 19 ini. Hal serupa juga sudah dilakukan oleh berbagai negara yang terpapar penyakit covid 19 ini, kebijakan lockdown atau karantina dilakukan sebagai upaya mengurangi interaksi banyak orang yang dapat memberi akses pada penyebaran virus corona. Penyebaran virus corona ini pada awalnya sangat berdampak pada dunia ekonomi yang mulai lesu, tetapi kini dampaknya dirasakan juga oleh dunia pendidikan. Kebijakan yang diambil oleh banyak negara termasuk Indonesia dengan meliburkan seluruh aktivitas pendidikan, membuat pemerintah dan lembaga terkait harus menghadirkan alternatif proses pendidikan bagi peserta didik maupun mahasiswa yang tidak bisa melaksanakan prosespendidikan pada lembaga pendidikan. Berdasarkan data yang diperoleh dari UNESCO, saat ini total ada 39 negara yang menerapkan penutupan sekolah dengan total jumlah pelajar yang terpengaruh mencapai 421.388 .462 anak. China sejauh ini memiliki jumlah pelajar yang paling banyak terpengaruh karena virus corona yaitu sekitar lebih dari 233 juta siswa. Sedangkan negara lainnya, hingga 13 Maret ada 61 negara di Afrika, Asia, Eropa, Timur Tengah, Amerika Utara dan Amerika Selatan yang telah mengumumkan atau menerapkan pembatasan pembelajaran sekolah dan universitas.

UNESCO menyediakan dukungan langsung ke negaranegara, termasuk solusi untuk pembelajaran jarak jauh yang inklusif. Kebijakan menutup sekolah di negara-negara tersebut, berdampak pada hampir 421,4 juta anak-anak dan remaja di dunia. Negara yang terkena dampak Covid19 menempatkan respons nasional dalam bentuk platform pembelajaran dan perangkat lain seperti pembelajaran jarak jauh. Dalam situs UNESCO dikemukakan bahwa pandemi corona ini mengancam 577 
juta pelajar di dunia.Sementara UNESCO menyebutkan, total ada 39 negara yang menerapkan penutupan sekolah dengan total jumlah pelajar yang terpengaruh mencapai 421.388.462 anak. Total jumlah pelajar yang berpotensi berisiko dari pendidikan pra-sekolah dasar hingga menengah atas adalah 577.305.660. Sedangkan jumlah pelajar yang berpotensi berisiko dari pendidikan tinggi sebanyak 86.034.287 orang.

Saat ini di Indonesia, beberapa kampus dan sekolah mulai menerapkan kebijakan kegiatan belajar mengajar dari jarak jauh atau kuliah online.Semua orang lantas mengambil jarak demi memutus rantai penularan COVID-19. Tempattempat ibadah kini mulai sepi, agendaagenda massa dihilangkan, karena SARSCoV-2 pula istilah 'Work From Home' (WFH) jadi melejit. Belum cukup, sekolah dan kampus ikut didaringkan.Lengkap sudah, virus corona juga memberikan dampak serius di sektor pendidikan, baik di Indonesia maupun secara global.pemerintah mengumumkan Ujian Nasional (UN) di tahun ini resmi ditiadakan. Mulai dari tingkat Sekolah Dasar (SD) hingga setingkat Sekolah Menengah Atas (SMA).Pemerintah telah meniadakan Ujian Nasional (UN) untuk tahun 2020.Tenaga dan peserta didik di seluruh dunia merasakan betul dampakyang luar biasa dari wabah virus corona yang pertama kali muncul di China.

Akibat pandemi yang sudah menyebar ke 156 negara itu, banyak sekolah-sekolah terpaksa diliburkan. ABC News melaporkan setidaknya ada 22 negara di tiga benua yang menutup sekolah mereka selama pandemi masih membayangi warganya.Sekolah-sekolah itu menampung ratusan juta siswa dari seluruh dunia.Dalam laporannya, ABC News juga mencatat ada 13 negara yang menutup sekolah di seluruh penjuru negeri. Korban akibat wabah covid-19, tidak hanya pendidikan ditingkat Sekolah Dasar/Madrasah Ibtidaiyah, Sekolah Menengah Pertama/Madrasah Stanawiyah, dan Sekolah Menengah Atas/Madrasah Aliyah, tetapi juga perguruan tinggi. Seluruh jenjang pendidikan dari sekolah dasar/ibtidaiyah sampai perguruan tinggi (universitas) baik yang berada dibawah Kementerian Pendidikan dan Kebudayaan RI maupun yang berada dibawah Kementerian Agama RI semuanya memperoleh dampak negatif karena pelajar, siswa dan mahasiswa "dipaksa" belajar dari rumah karena pembelajaran tatap muka ditiadakan untuk mencegah penularan covid-19. Padahal tidak semua pelajar, siswa dan mahasiswa terbiasa belajar melalui Online. Apalagi guru dan dosen masih banyak belum mahir mengajar dengan menggunakan teknologi internet atau media sosial terutama di berbagai daerah.

Tujuan dari penelitian ini adalah untuk mendapatkan informasi mengenai dampak dan kendala dari pandemik COVID-19 terhadap kegiatan belajar mengajar di Perguruan Tinggi di Bali dan menggunakan metode kualittaif ekploratif.

\section{METODE PENELITIAN}

Penelitian menggunakan metode studi kasus eksplorasi dan pendekatan penelitiannya menggunakan metode studi kasus kualitatif yang digunakan untuk mendapatkan informasi kendala dan akibat dari pandemic COVID-19 terhadap kegiatan proses belajar mengajar di perguruan tinggi. Ukuran sampeldidasarkan pada pencapaian kedalaman dan kekayaan deskripsi, bukan ukuran sampel.Menurut Guetterman (2015), ukuran sampel bukan masalah opini representatifdan pandangan, tetapi lebih merupakan masalah kekayaan informasi. Dalam penelitian ini, responden sebanyak 6 orang mahasiswa, dosen dan orang tua 
mahasiswa. Untuk tujuan kerahasiaan,respondendiberi inisial R1, R2, R3, R4, R5 dan R6. Wawancara semiterstruktur dilakukan dan daftar pertanyaandisusun untuk wawancara dikembangkan berdasarkan literatur terkait.Responden untuk penelitian ini adalah para dosen dan orang tua mahasiswa di sebuah perguruan tinggi di Bali.Tabel 1.

\begin{tabular}{|c|c|c|c|c|}
\hline Inisial & Jenis Kelamin & Usia & Status & Pendidikan \\
\hline R1 & Laki-laki & 22 & Single & Mahasiswa S1 \\
\hline R2 & Perempuan & 21 & Single & Mahasiswa S1 \\
\hline R3 & Perempuan & 38 & Menikah & S1 \\
\hline R4 & Laki-laki & 46 & Menikah & S1 \\
\hline R5 & Perempuan & 44 & Menikah & S1 \\
\hline R6 & Laki-laki & 36 & Menikah & S1 \\
\hline
\end{tabular}

Profil Responden

Metode pengumpulan dengan primer denganwawancara semi-terstruktur sedangkan data sekunder dikumpulkan dari data yang dipublikasikan seperti artikel jurnal-jurnal dan buku.Penelitian ini terbatas pada ukuran sampel 6responden yang tinggal di beberapa Kota di Bali.Penelitian ini adalah studi kasus eksplorasi dan sampel dipilih menggunakan metode purposive sampling.Dalam penelitian kualitatif, teknik purposive sampling adalah metode yang digunakan untuk mencapai tujuan penelitian tertentu. Tidak ada batasan jumlah responden untuk membuat sampel purposive, asalkan informasi yang diinginkan dapat diperoleh dan dihasilkan (Bernard, 2002).Untuk melakukan penelitian studi kasus, Creswell (2013) memberikan pengamatan dan beberaparekomendasi ukuran sampel, yang berkisar tidak lebih dari empat hingga lima kasus. Dalam studi kasus para responden diwawancarai hingga saturasi data tercapai dan tidak ada lagiinformasi baru dapat diperoleh (Guest et al., 2006; Krysik dan Finn, 2010).Semua responden menyediakan lembar informasi sebelum wawancara.Untuk tempatwawancara dilakukan di lokasi yang nyaman bagi para responden.Semua wawancara, dengan izin dan persetujuan yang ditandatangani, direkam secara audio dan kemudian ditranskrip secara verbal.Analisis dan interpretasi data adalah bagian paling kritis dari penelitian kualitatif.Pedoman analisis data tematik (Creswell, 2009) digunakan.Ini dianggap yang paling tepat untuk setiap penelitian yang berupaya mengeksplorasi beberapa interpretasi (Alhojailan, 2012).Dalam analisis tematik "semua kemungkinan interpretasi adalah mungkin" (Alhojailan, 2012, hal. 10). Alasan untuk memilih analisis tematik adalah bahwa "pendekatan tematik yang ketat dapat menghasilkan analisis mendalam yang menjawab pertanyaan penelitian tertentu" (Braun dan Clarke, 2006, hal. 97).Setelah analisis yang ketat, peneliti menggambarkan temuan, sesuai dengan empat tema utama. Untuk menggali dan mendapatkan informasi dampak atau kendala pandemic COVID terhadap kegiatan proses belajar mengajar dibuat beberapa pertanyaan penelitian, diajukan pertanyaan-pertanyaan berikut :

1. Bagaimanakah dampak pandemic COVID 19 yang dialami mahasiswa pada kegiatan belajar mengajar?

2. Bagaimanakah dampak pandemic COVID 19 yang dialami orang tua pada kegiatan belajar mengajar?

3. Bagaimanakah dampak pandemic COVID 19 yang dialami dosen pada kegiatan belajar mengajar?

\section{HASIL DAN PEMBAHASAN}

Tujuan dari penelitian ini adalah untuk mendapatkan informasi mengenai dampak dari pandemic COVID-19 terhadap kegiatan belajar mengajar di Sekolah Dasar di Tangerang. Semua tanggapan peserta adalah kutipan asli, dan mereka telah dikutip sebagaimana dinyatakan oleh para responden. Seorang dari responden (R6) memberikan pernyataan : "para mahasiswa di "paksa" belajar jarak jauh tanpa sarana 
dan prasarana memadai di rumah " (R6). Responden lain memberikan pernyataan sebagai berikut : "Mahasiswa belum ada budaya belajar jarak jauh karena selama ini sistem belajar dilaksanakan adalah melalui tatap muka."(R5). Dia juga menambahkan pernyataan bahwa: "dosen tidak semua mahir menggunakan teknologi internet atau media sosial sebagai sarana pembelajaran"(R5). Beberapa responden memberikan pernyataan : "belum ada sistem baku yang menjadi pegangan dalam pembelajaran jarak jauh" (R3). Mirip dengan ini, responden lain memberikan pernyataan sebagai berikut: belum ada sistem yang baku dalam mengawasi pelajar, siswa dan dosen dalam menjalankan proses belajar melalui jarak jauh" (R2). Responden lainnya menambahkan: "biaya pembelian kuota internet bertambah" (R1). Seorang responden mennyatakan bahwa: "saya sebagai orang tua harus menyiapkan biaya yang lebih banyak, kemudian ikut mengawasi anak dalam belajar online"(R3)."perlu biaya tambahan pembelian pulsa kuota internet" (R4). "Saya pikir, anak-anak kehilangan jiwa social, jika di kampus mereka biasa berinteraksi dengan banyak orang danmencari pengalaman sebanyak mungkin"(R5). Beberapa responden memberikan pernyataan sebagai berikut: "kuliah diliburkan terlalu lama membuat anak-anak jenuh" (R6). Mirip dengan ini,responden lain memberikan pernyataan sebagai berikut: " anak-anak mulai jenuh di rumah dan pingin segera ke kampus dan melaksankan aktivitas-aktivitas seperti biasanya saat kondisi normal" (R4). Beberapa responden lainnya memberikan pernyataan sebagai berikut: "pembelajaran menjadi kurang efektif, terlebih sinyal yang kurang bagus membuat semuanya tersendat dan kurang jelas, bahkan bisa memutuskan pembicaraan begitu saja" (R1). Mirip dengan ini,responden lain memberikan pernyataan sebagai berikut "saya sering mengalami mis komunikasi akibat sinyal yang kurang bagus" (R2). Beberapa responden memberikan pernyataan : "pengeluaran dosen bertambah untuk pembelian kuota" (R3). Mirip dengan ini,responden lain memberikan pernyataan sebagai berikut: "dosen lebih banyak lagi beli kuota internet" (R4). Beberapa responden memberikan pernyataan : "dosen merasa jenuh berada di rumah terus dan ingin segera kembali ke kampus berinteraksi dengan mahasiswa" (R5). Mirip dengan ini,responden lain memberikan pernyataan sebagai berikut: "kejenuhan dosen berada di rumah mulai terasa" (R6).

Sebanyak 6 responden telah memberikan pernyataan dan pendapat yang akan dijelaskan dan dibahas sebagai berikut.

Dampak terhadap Mahasiswa : Berapa dampak yang dirasakan mahasiswa pada proses belajar mengajar di rumah adalah para mahasiwa merasa dipakasa belajar jarak jauh tanpa sarana dan prasarana memadai di rumah. Fasilitas ini sangat penting untuk kelancaran proses belajar mengajar, untuk pembelajaran online di rumahnya seharusnya disediakan dulu fasilitasnya seperti laptop, komputer ataupun hand phone yang akan memudahkan mahasiswa untuk menyimak proses belajar mengajar online. Kendala selanjutnya yaitu mahasiswa belum ada budaya belajar jarak jauh karena selama ini sistem belajar dilaksanakan adalah melalui tatap muka, mahasiswa terbiasa berada di kampus untuk berinteraksi dengan temanteman dan dosennya, dengan adanya metode pembelajaran jarak jauh membuat para mahasiswa perlu waktu untuk beradaptasi dan mereka menghadapi perubahan baru yang secara tidak langsung akan mempengaruhi daya serap belajar mereka. Dampak selanjutnya yang dialami murid yaitu kampus diliburkan terlalu lama 
membuat anak-anak jenuh, Kemudian mahasiswa akan kehilangan jiwa sosial, jika di kampus mereka bisa berinteraksi dengan teman-temnanya tetapi kali ini mereka tidak bisa dan hanya sendiri di rumah bersama orang tua, interaksi dengan sesama teman, dosen dan orang-orang disekitar akan menjadi berkurang. Adanya wabah Covid-19 memaksa para mahasiswa harus menggunakan teknologi, sehingga suka tidak suka dan mau tidak mau harus belajar dan siap mengajar melalui jarak jauh dengan menggunakan teknologi.

Dampak terhadap orang tua : Kendala yang dihadapi para orang tua adalah adanya penambahan biaya pembelian kuota internet bertambah, teknologi online memerlukan koneksi jaringan ke internet dan kuota oleh karena itu tingkat penggunaaan kuota internet akan bertambah dan akan menambah beban pengeluaran orang tua. Untuk melakukan pembelajaran online selama beberapa bulan tentunya akan diperlukan kuota yang lebih banyak lagi dan secara otomatis akan meningkatkan biaya pembelian kuota internet. Kendala selanjutnya yang dirasakan orang tua yaitu mereka juga secara tidak langsung ikut mengawasi dalam kegiatan pembelajaran online

Dampak terhadap dosen : Dampak yang dirasakan dosen yaitu tidak semua mahir menggunakan teknologi internet atau media sosial sebagai sarana pembelajaran, beberapa dosen senior belum sepenuhnya mampu menggunakan perangkat atau fasilitas untuk penunjang kegiatan pembelajaran online dan perlu pendampingan dan pelatihan terlebih dahulu. Dan kompetensi dosen dalam menggunakan teknologi akan mempengaruhi kualitas program belajar mengajar oleh karena itu sebelum diadakan program belajar online para dosen wajib untuk diberikan pelatihan terlebih dahulu. Berapa dampak yang dirasakan dosen yaitu pada proses belajar mengajar online di rumah tanpa sarana dan prasarana memadai di rumah. Fasilitas ini sangat penting untuk kelancaran proses belajar mengajar, untuk pembelajaran online di rumahnya seharusnya disediakan dulu fasilitasnya seperti laptop, computer ataupun hand phone yang akan memudahkan dosen untuk memberikan materi belajar mengajar secara online. Kendala selanjutnya yaitu para dosen belum ada budaya belajar jarak jauh karena selama ini sistem belajar dilaksanakan adalah melalui tatap muka, para dosen terbiasa berada di kampus untuk berinteraksi dengan mahasiwa, dengan adanya metode pembelajaran jarak jauh membuat para dosen perlu waktu untuk beradaptasi dan mereka menghadapi perubahan baru yang secara tidak langsung akan mempengaruhi kualitas hasil belajar. Adanya wabah Covid-19 memaksa para dosen harus menggunakan teknologi, sehingga suka tidak suka dan mau tidak mau harus belajar dan siap mengajar melalui jarak jauh dengan menggunakan teknologi. Kendala yang dihadapi para dosen adalah adanya penambahan biaya pembelian kuota internet bertambah, teknologi online memerlukan koneksi jaringan ke internetdan kuota oleh karena itu tingkat penggunaaan kuota internet akan bertambah dan akan menambah beban pengeluaran dosen. Untuk melakukan permbelajaran online selama beberapa bulan tentunya akan diperlukan kuota yang lebih banyak lagi dan secara otomatis akan meningkatkan biaya pembelian kuota internet. Kompetensi dosen dalam memanfaatkan teknologi dan menguasai teknologi untuk pembelajaran dituntut untuk meningkat dengan cepat untuk merespon online Home Learning.

\section{PENUTUP}

Dampak pandemic COVID 19 yang dialami mahasiswa pada kegiatan belajar mengajar 
yaitu para mahasiwa merasa dipakasa belajar jarak jauh tanpa sarana dan prasarana memadai di rumah, selain itu, mahasiswa kehilangan jiwa sosial karena kurang bergaul bersama teman-teman di kampus.

Dampak pandemic COVID 19 yang dialami orang tua pada kegiatan belajar mengajar yaitu orang tua mengalami penambahan biaya pembelian kuota internet bertambah

Dampak pandemic COVID 19 yang dialami dosen pada kegiatan belajar mengajar, yaitu kurang maksimalnya pembelajaran karena sebagian besar dosen kurang mahir dalam penggunaan teknologi.

\section{DAFTAR PUSTAKA}

Asbari. M.,Nurhayati. W.,Purwanto.A, (2020). The effect of parenting style and genetic personality on children character development. Jurnal Penelitian dan Evaluasi Pendidikan : 23(2). DOI: https://dx.doi.org/10.21831/pep.v $23 \mathrm{i} 2.28151$

Asbari, M., Wijayanti,L.M, Hyun, C.C., Purwanto, A., Santoso, P.B,(2020).Effect of Tacit and Explicit Knowledge Sharing on Teacher Innovation Capability,Dinamika Pendidikan, 14(2),47- 59, https://doi.org/10.15294/dp.v14i2.2 2732

Asbari, M., Wijayanti, L., Hyun, C., Imelda, D., yanthy, E., \& PURWANTO, A. (2020). HARD SKILLS ATAU SOFT SKILLS: MANAKAH YANG LEBIH PENTING BAGI INOVASI GURU. Edumaspul: Jurnal Pendidikan, 4(1), $\quad 1-20$. https://doi.org/10.33487/edumaspul .v4i1.333

Asbari, M., Nurhayati, W., Purwanto, A., \& Putra, F. (2020).Pengaruh Genetic Personality dan Authoritative Parenting Style terhadap Pendidikan Karakter di Aya Sophia Islamic School. Edumaspul: Jurnal Pendidikan, 4(1), 142-155. https://doi.org/10.33487/edumaspul .v4i1.341

Burd, B. and Buchanan, L. (2004), "Teaching the teachers: teaching and learning online", Reference Services Review, Vol. 32 No. 4, pp. 404-412.

https://doi.org/10.1108/009073204 10569761

Burd, B. and Buchanan, L. (2004), "Teaching the teachers: teaching and learning online", Reference Services Review, Vol. 32 No. 4,pp. 404-412.

https://doi.org/10.1108/009073204 10569761

Chakraborty, M. and Muyia Nafukho, F. (2014), "Strengthening student engagement: what do students want in online courses?", European Journal of Training and Development, Vol. 38 No. 9, pp. 782-802. https://doi.org/10.1108/EJTD-112013-0123

Drago, W. and Wagner, R. (2004), "Vark preferred learning styles and online education", Management Research News, Vol. 27 No. 7, pp. 113.https://doi.org/10.1108/0140917 0410784211

Leslie, H. (2019), "Trifecta of Student Engagement: A framework for an online teaching professional development course for faculty in 
higher education", Journal of Research in Innovative Teaching \& Learning, Vol. aheadof-print No. ahead-of-print.

https://doi.org/10.1108/JRIT-102018-0024

Lewis, S., Whiteside, A. and Dikkers, A. (2015), "Providing Chances for Students to Recover Credit: Is Online Learning a Solution?", Exploring Pedagogies for Diverse Learners Online (Advances in Research on Teaching, Vol. 25), Emerald Group Publishing Limited, pp. 143-157. https://doi.org/10.1108/S1479368720150000027007

Pillai, R. and Sivathanu, B. (2019), "An empirical study on the online learning experience of MOOCs: Indian students' perspective", International Journal of Educational Management, Vol. 34 No. 3, pp. 586-609. https://doi.org/10.1108/IJEM-012019- 0025
Purwanto, A., Asbari, M., \& Santoso, P.(2019). Does Culture, Motivation, Competence, Leadership,Commitment Influence Quality Performance? Jurnal Inovasi Bisnis, 6(2), 201- 205.DOI: https://doi.org/10.35314/inovbiz.v7 i2.1210

Zhao, F. (2003), "Enhancing the quality of online higher education through measurement", Quality Assurance in Education, Vol. 11 No. 4, pp. 214-221.

https://doi.org/10.1108/096848803 10501395 